\title{
The History and Functioning of the Forest Department in Madras Presidency during 1856-1882
}

\author{
S. Kamini* \\ PSGR Krishnammal College for Women, Coimbatore.
}

(Received 03 June 2020)

\begin{abstract}
The demand for the Indian timbers increased in the beginning of the 19th century. This forced the Colonial Government to depute officials for formulating new policies and enacting forest acts in British occupied territories of India. Madras was one such presidency where the timber was in abundant and the new policies of the government expedited the deforestation of forest reserves in south India after $1800 \mathrm{CE}$. The scientific forestry in South India was started in 1806 after the appointment of Captain Watson, a Police officer as first conservator of India. This paper reconnoitres the history and functioning of the Forest department in Madras presidency during the period between H.F. Cleghorn's appointment in 1856 as the first regular Conservator of Forests and the enactment of the first Madras Forest Act in 1882.
\end{abstract}

Key words: Conservator, Forests, Forests acts, Plantations, Madras presidency, Revenue and Expenditure, Timber.

\section{Introduction}

The Madras presidency was the southernmost province of the British Indian Empire surrounded by the State of Mysore and the British province of Coorg. It was bounded on the east by the Bay of Bengal and the Gulf of Mannar from the Chilka Lake to Cape Comorin, and on the west by the Arabian Sea. On its northern boundaries from east to west were Orissa, Central provinces, Nizam's dominions and the southernmost districts of Bombay presidency. The Madras presidency comprised of 26 districts of which Madras was one. ${ }^{1}$ It possessed two large mountain systems in the Eastern and Western Ghats. The principal rivers were Godavari, Krishna, Palar, Pennar, Ponniyar, Cauvery, Vaigai and Tambraparni.

DOI: 10.16943/ijhs/2020/v55i3/156958

*Email: kaminicsekaran@gmail.com, kamini@psgrkcw.ac.in

${ }^{1}$ A Statistical Atlas of the Madras Presidency, Government Press, Madras,1936, p.1

\section{Madras Presidency and its Forests}

The erstwhile Madras Presidency was characterized by a tropical climate except for the highland plateaus of the Nilgiris and Palnis where as a result of elevation (over 5000 feet), the climate was mildly temperate. The total extent of forests was 6, 734 sq. miles and of reserved lands (comprising mostly of ex-zamin forests) about 1491 sq. miles. The land under forests constituted about seventeen percent of the total land area of the State (Madras Forest Department Souvenir, 1959, p. i). The forests of the Madras presidency served chiefly the requirements of the agricultural population for fuel and building material and valuable ones yielding a considerable amount of better class timber for public works such as the railways etc. The most valuable forests were those of teak found in Malabar, the Nilgiris and Coimbatore (Thurston 2005, p. 113).

The forest occurred mainly in the hills, though a few 
patches were found in the plains also. To the west of the State lied the unbroken range of the Western Ghats. On the east coast, the low interrupted chain of hills generally constitutes the Eastern Ghats, though locally known by different names. A spur of the Western Ghats lying in Coimbatore district is known as the Anamalais. Its extension in Madurai district is called as the Palnis, where the hill station of Kodaikanal is situated. Apart from the main ranges and plateaus, small hill masses dot most of the districts, such as the Javadis of North Arcot, the Shevroys of Salem, the Sirumalais of Madurai, etc. Sal forests occurred chiefly in the northern districts of Ganjam, red sanders wood in Cuddapah and North Arcot, sandal in Coimbatore and Coorg, Hardwickia in Anantapur and Bellary (Thurston 2005, p. 113).

\section{The Colonial Forests Administration in India}

The British colonial expansion took place at massive costs of forest resources in different parts of the globe. Initially, the North American continent supplied most of the timber required for the shipbuilding industry in Britain. After the American Revolution, timber imports from America were ceased. Having exhausted their timber supplies from America, the British depended upon Scandinavian countries and India for their shipbuilding lumber. Indian timbers became heavily in demand. The Bombay dockyard on the west coast and Coring (Kakinada), a port town on the east coast, emerged as India's main shipbuilding centres. It consumed an enormous quantum of accessible forests soon leading to a shortage in timber for shipbuilding. $^{2}$ The East India Company began to exploit South Indian forests to procure timber for shipbuilding. The Godavari region was found suitable with a good stock of teak timber.

\subsection{Forest Administration in Madras Presidency}

The first organised attempt to log forest for teak on the west coast dates back to 1796, when Surgeon William Maconochie established a timber syndicate in Malabar district (Stebbing 1922, p. 68). The process of deforestation in South India was expedited after $1800 \mathrm{CE}$. The Court of

\footnotetext{
${ }^{2}$ http: //www. environmentandsociety.org/node/7553
}

Directors sent a dispatch to the company government in 1805 with instructions to ascertain as to what extent the king's navy could depend upon teak timber supplies from the forests of the Malabar district. The East India Company's government also appointed a committee to enquire into the status of teak forests in the Malabar and Canara districts (Ribbentrop, 1900, p. 68).

The scientific forestry in South India started in 1806 and subsequently Captain Watson, a Police Officer was appointed as the first Conservator of India, with Malabar and Travancore as his jurisdiction to organise the felling of fine timbers like teak for the British Navy (Forest Management in Tamil Nadu 2010, p. 1). A proclamation was issued in 1807 asserting the Company's right of sovereignty over the forests and forbidding the felling of timber by private individuals (Brandis 1897, p. 19). After the abolition of the Conservator's post in 1823, the control over the forests was vested with the District Collector till 1859. Excessive exploitation of teak forests emerged as a problem especially from 1830 onward. The ruler of Travancore presented a petition to the Bombay government in 1830 highlighting the unrestricted cutting of teak trees in the west coast forests. In 1837, Clementson, the Collector of the Malabar district reported to the Board of Revenue that 33,000 teak logs were exported from the Malabar district. In 1838, he also reported severe deforestation due to over exploitation of the teak forests. The necessity for scientific advice in the management of forests was gradually realised by the administrators and in 1847, Alexander Gibson was appointed as Conservator of Forests by the Bombay Government in addition to his other duties. In 1854, Lt. James Michael was appointed as the Superintendent of the Anaimalai Forests after his training in Moulmein, Burma. It was he who recognised the advantage of using saw in the place of the axe for felling the trees (One Hundred Years of Indian Forestry 1961, p. 74).

\subsection{Large scale clearance and conversion of forests into plantations}

The history of plantations in the country can be traced to the artificial teak plantations at Nilambur in Kerala during the 1840s. The initiative for teak plantations was taken by the then Malabar Collector H. V. Connolly, on a suggestion from the Court of Directors of the British Administration to ensure a steady supply of teak timber needed for the Bombay Navy Dockyard. A study by H. V. 
Connolly revealed that an uninterrupted annual supply of $2230 \mathrm{~m}^{3}$ of teak timber was necessary to build at least one ship on a permanent basis. As teak takes about sixty years to mature and 2000 trees may yield $2230 \mathrm{~m}^{3}$ of timber, he at first decided to raise a plantation of 1,20,000 teak trees in a sustained manner (Karunakaran 2012, p. 93). In the beginning, H. V. Connolly encountered several difficulties to his proposed plantation programme. The first obstacle was finding adequate suitable land for plantation which was solved by obtaining sanction from the British Administration to purchase 6700 hectares of land at Nilambur (Karunakaran 2012, p. 93). The real problem faced was in getting the teak seeds germinated. He sought the advice of White (Cotton Farm Superintendent) and Monshier Perottatti (Superintendent of Botanical Garden, Pondicherry). They suggested certain pre-treatment measures for teak seeds and permitted H. V. Connolly to try all such measures (Karunakaran 2012, p. 94). The natives resentment against the British policies were brewing and in 1855 and Connolly was assassinated by locals in his bungalow at Kozhikode (Karunakaran 2012, p. 96).

\subsection{Hugh Francis Cleghorn's work in Madras Presidency}

In 1856, H. F. Cleghorn was appointed as the first regular Conservator of Forests in Madras Presidency (Ribbentrop 1900, p. 71) (Table 1). He laid the foundation for an effective system of forest conservancy in Madras at a time when forestry was very little known in the rest of India. Alexander Gibson and H. F. Cleghorn both strongly advocated that the Government should claim and exercise the proprietary right to all such forests which could not clearly be proved to be private property, a stricter conservative control, and above all an intermediate restriction on shifting cultivation in the hills (Ribbentrop 1900, p. 71). Both were allowed to obtain a definite hold over large areas of forest owing to the mistaken policy introduced by Government departments in the early days for securing the requirements of timber. Their secondary objective was to assure the Government to meet its full timber demands for the dockyards, gun-carriage factories, public works, and so forth (Stebbing, 1922, p. 220).
Table 1 Organisation of Forest Departments in various Provinces and Administrations.

\begin{tabular}{|l|c|}
\hline Province/Administration & Year \\
\hline Bombay & 1847 \\
\hline Madras & 1856 \\
\hline North West Provinces- & \\
Under Commissioner in & 1860 \\
Under conservator in & 1868 \\
\hline Central Provinces & 1860 \\
\hline Oudh & 1861 \\
\hline Punjab & 1864 \\
\hline Coorg & 1864 \\
\hline Bengal & 1864 \\
\hline Assam & 1868 \\
\hline Berar & 1868 \\
\hline
\end{tabular}

Source: Negi, 1994.

\subsection{Ootacamund Eucalyptus plantations}

H. F. Cleghorn during his tenure addressed the Government on the subject of the fuel supply to Ootacamund, Wellington and other stations in the hills. The first plantation made on the Nilgiri Hills was by Captain Campbell on a site of 600 acres within three miles of Wellington. By April 1858, eight acres had been planted with Acacia lophantha (Stebbing 1922, p. 220). E. B. Thomas, the Collector of Coimbatore who spent few months each year at Ootacamund, also planted 8000 Australian trees of different species at a cost of Rs.400, and re-sown the old denuded forests. The Nilgiri Hills was not the only locality in the Presidency where the fuel question was proving a serious difficulty. The city of Madras was experiencing considerable trouble in obtaining sufficient supplies of timber and fuel. In almost every district of this Presidency, the private individuals frequently asked, "which was the best kind of tree to be grown for firewood?" There had been a great demand for wood and fuel in the vicinity of the railways also. According to the published records of the late Military Board in Madras, the consumption of firewood and charcoal was estimated at 98,652.5 tons per annum in 1852 (Stebbing 1922, p. 316).

The necessity of providing handbooks to Indian Forest Officers was felt since the inception of the department. Subsequently, H. F. Cleghorn published his work on the 
"Forests and Gardens of South India" and his successor in Madras, Colonel Richard Henry Beddome completed his work "Forest Flora of North-West and Central India" (Brandis 1897 p. 58). In Mysore, a separate Forest Department was inaugurated with appointment of Major A. Hunter as its Conservator on 11th January 1864. H. F. Cleghorn was associated with Dietrich Brandis who was then deputed as the first Inspector General of Forests to advise the Government of India in the general organisation of forest administration in January 1864. His work was acknowledged by Dietrich Brandis. A public Resolution by the Government of India dated 10th January 1865 , designated Cleghorn as the "Founder of Forest Conservancy in India” (Stebbing 1922, p. 324). The British Government not only appointed officials for the procurement of the forest resources but also enacted laws in order to exploit the forest wealth and to restrict people's entry into the forests.

\section{Charter of the Indian forests}

In 1855, Lord Dalhousie, the then Governor-General promulgated for the first time an outline for forest conservancy for the whole country by the issue of a memorandum of the Government of India dated 3rd August 1855 which was later regarded as the "Charter of Indian Forests”. In the year 1856, Dietrich Brandis was appointed as Superintendent of Forests in Pegu (Burma) and later came to serve in India. He was a scientifically trained forester, having received his training in Germany, the only fine training ground in forestry at that time, besides Nancy in France. The foundation of the present structure of the forest department was laid by Dietrich Brandis. He was also responsible for starting forestry training and research in India (Negi 1997, p. 24).

In the year 1857, the royal proclamation declared Queen Victoria as the Empress of India after which railway construction received tremendous impetus. The country began to be connected by a network of railway lines and roads (Rawat 1991, p. 155). To meet the growing demands, sound principles of conservation were all but abandoned and forest destruction went unabated.
Table 2 Sources of Fuel supply to Madras Railways (in tons).

\begin{tabular}{|l|c|c|c|}
\hline Districts & Government & Private & Total \\
\hline $\begin{array}{l}\text { Nizam's } \\
\text { Dominions }\end{array}$ & - & 2,550 & 2,550 \\
\hline Bellary & - & 1,120 & 1,120 \\
\hline Cuddapa & 8,860 & 1,800 & 10,660 \\
\hline North Arcot & 2,750 & 23,440 & 26,190 \\
\hline Mysore & - & 850 & 850 \\
\hline Salem & 650 & 10,750 & 11,400 \\
\hline Coimbatore & 400 & - & 400 \\
\hline Malabar & - & 15,250 & 15,250 \\
\hline Total & 12,660 & 55,750 & 68,420 \\
\hline
\end{tabular}

Source: Brandis, 1883, p. 40.

\subsection{Forest Acts}

In the early 19 th century, forests were often felled under British supervision for the reason of defence. The onslaught on forests became heavier in the mid-19th century with the huge new demand of teak for railway sleepers, fuel for railway locomotives, and timber for shipbuilding (Table 2). Private contractors took forest patches on lease and cut down trees in large numbers. In several parts of India, the destruction distressed the pattern of vegetation and wildlife (Roy 2012, p. 150). The establishment of the Forest Department in the year 1864 and the enactment of the Indian Forest Act the next year (1865) were the first steps towards formal legal restraints on access to forest resources. This act empowered the colonial rulers to declare any Jungle or tree cover as Government Forest (Rawat 1993, p. 75). Act VII of 1865 proved seriously defective for certain portions of the forests of British India to which it applied. A revised Bill and a Memorandum explaining the necessity for new legislation were submitted to the Government of India by Brandis in 1868. The local Governments were asked to express their opinions on the draft Bill, which was then redrafted and again considered by the Government of India in 1871(Stebbing 1923, p. 469).

The defects of Act VII of 1864 were discussed in detail at a Forest Conference held at Allahabad in 1873-74. As a result, a new Act (Act VII of 1878) was passed in 1878 and it extended to all Provinces of British India with the exception of Madras, Coorg, Burma, Bihar, the Hissar district 
of the Punjab, Ajmer, and Baluchistan. The act aimed at improving on the inadequacies of the Indian Forest Act of 1865. By this Act, the British Administration acquired the sovereignty of all wastelands which by definition included forests and it also enabled the administration to demarcate reserved and protected forests (Balyani 2012 p. 46). This act even considered the accepted daily activities like slash and burn cultivation and grazing in the forest land of local villagers/farmers a punishable offence with imprisonment for a term up to six months (Rawat 1993).

The Government declared that the Indian Forest Act could not be extended to Madras, as the formation of reserves, as contemplated by the act could not be accomplished. The rights of the villagers over the wastelands and jungles were considered to be of such a nature as to prevent the government from forming independent states property and thus Madras preferred to legislate locally. Subsequently, the Madras Board of Revenue wrote the following on 16 April 1868:

All the jungles and forests of this Presidency are within village boundaries, and the people residing in or near them, have, from time immemorial, had the right to take leaves for manure, firewood for their own use and timber for agricultural purposes, to graze their cattle at certain periods. These rights have been repeatedly recognised by the Government, and are scrupulously respected. When, therefore these and other similar existing privileges, as well as the rights of way which the Act in this Presidency will be very limited, and every prosecution under it may be met by the allegation that a right previously existed which vitiates the application of the act. When the forest is the absolute property of Government, no special Act is necessary to declare it such. ${ }^{3}$

Consequently, Dietrich Brandis was then deputed to Madras in 1881 which resulted in the passing of the Madras Forest Act of 1882 and it came into effect from 1st January 1883 (Ribbentrop 1900, p. 16). By this Act, the Government empowered the Forest Settlement Officers to enquire into and to commit on record all private rights in areas to be selected for the constitution as re-

\footnotetext{
${ }^{3}$ Cpsindia.org accessed 2 June 2020.
}

served forests. ${ }^{4}$ Based upon the decision of the officer, appeals could be made to the District Court within thirty days in case of claims involving proprietary rights and to the Revenue Officer within sixty days in case of rights of way, rights to pasture, to forest produce or to the watercourse. ${ }^{5}$ When the inquiry was completed and all claims disposed of and settled, the forest would be declared by the Government as reserved and thereafter no fresh rights could accrue therein. ${ }^{6}$ The Act contained the provisions required for the protection of reserved forests ${ }^{7}$ but there was no provision for the constitution of village forests.

This Act further provided for the "control of timber in transit", for the establishment of a "forest court" in case of difficulties of appeal in the constitution of reserved forests, for "penalties and procedure", for "cattle trespass," for the duties of "forest officers" to declare the forest, property of the State, which once settled legally constituted the permanent forest property of the State and cannot be alienated or dis-afforested without the consent of the GovernorGeneral in Council. ${ }^{8}$

\section{Conclusion}

A statement of revenue, expenditure and surplus from Madras Forests for the years 1859-60 and 1876-77 to 1882-83 has been listed in Table 3 and 4. It can be seen that from a small beginning, the department emerged as a very expedient and profitable to the British Raj. Though the resources started dwindling due to severe exploitation, the forest returns increased progressively from 1876-77 onwards. The Department progressed to make a significant contribution to the net financial resources of the Madras Presidency. Subsequently, the Colonial Forest Policy was also formulated towards the vulnerability of Indian forests. Though the policy was able to quantify the economic level of exploitation under the British Raj, the other vital resources such as flora and fauna were brought under severe threat and loss to them were beyond measure. It ultimately affected the environmental equilibrium of the Madras Presidency.

\footnotetext{
${ }^{4}$ Madras Forest Act, 1882 (Act no. V of 1882, sections 1-9)

${ }^{5}$ Madras Forest Act, 1882 (Act no. V of 1882, sections 10 and 15).

${ }^{6}$ Madras Forest Act, 1882 (Act no. V of 1882, sections 16 and 18).

${ }^{7}$ Madras Forest Act, 1882 (Act no. V of 1882, sections 21).

${ }^{8}$ Manual of the Administration of the Madras Presidency, Part II, 1885 , p. 314
} 
Table 3 Financial Results of Conservancy for 1859-60.

\begin{tabular}{|c|c|c|c|c|c|c|c|c|c|}
\hline \multirow[t]{2}{*}{$\begin{array}{l}\text { Name of } \\
\text { the Forests }\end{array}$} & \multicolumn{3}{|c|}{$\begin{array}{c}\text { Receipts from sale } \\
\text { of timber etc. }\end{array}$} & \multicolumn{3}{|c|}{$\begin{array}{l}\text { Disbursements including } \\
\text { the cost of establishments } \\
\text { \& contingent charges }\end{array}$} & \multicolumn{3}{|c|}{$\begin{array}{c}\text { Balance in favour } \\
\text { of Government }\end{array}$} \\
\hline & Rupees & Anna & Paise & Rupees & Anna & Paise & Rupees & Anna & Paise \\
\hline Anaimalai & $2,65,953$ & 1 & 0 & 22,484 & 9 & 4 & & & \\
\hline Sigur & 2,593 & 3 & 6 & 2,147 & 15 & 3 & $2,43,468$ & 7 & 8 \\
\hline Salem & 29,482 & 6 & 7 & 4,040 & 6 & 6 & 445 & 4 & 3 \\
\hline $\begin{array}{l}\text { Canara (May } \\
\text { to December } \\
1859)\end{array}$ & 87,921 & 0 & 11 & 29,037 & 9 & 10 & 25,442 & 0 & 2 \\
\hline $\begin{array}{l}\text { North } \\
\text { Canara } \\
\text { (January to } \\
\text { April } 1860\end{array}$ & $1,11,513$ & 0 & 1 & 29,460 & 0 & 7 & 58,883 & 7 & 1 \\
\hline $\begin{array}{l}\text { South } \\
\text { Canara } \\
\text { (January to } \\
\text { April 1860) }\end{array}$ & 5,069 & 1 & 10 & 907 & 4 & 3 & 82,052 & 15 & 6 \\
\hline $\begin{array}{l}\text { Nilgiris } \\
\text { Sholas }\end{array}$ & 909 & 14 & 0 & 50 & 0 & 6 & 4,161 & 13 & 7 \\
\hline Total & $5,03,441$ & 11 & 11 & 88,127 & 14 & 3 & $4,15,313$ & 13 & 8 \\
\hline Pay of the Co & ervator & $\begin{array}{l}\text { duct } G \\
\text { orests, }\end{array}$ & $\begin{array}{l}\text { eral } \mathrm{Cl} \\
\text { tablish }\end{array}$ & rges & gent & es etc & 21,722 & 12 & 3 \\
\hline & & Act & al Profit & & & & $3,93,591$ & 1 & 5 \\
\hline
\end{tabular}

Source: Stebbing 1982, p. 307.

Table 4 Results of Forest Management from 1876-77 to 1882-83.

\begin{tabular}{|l|c|c|c|}
\hline Year & $\begin{array}{c}\text { Receipts } \\
\text { (Rupees) }\end{array}$ & $\begin{array}{c}\text { Expenditure } \\
\text { (Rupees) }\end{array}$ & $\begin{array}{c}\text { Net Return to State } \\
\text { (Rupees) }\end{array}$ \\
\hline $1876-77$ & $4,15,372$ & $4,13,970$ & 1402 \\
\hline $1877-78$ & $4,04,164$ & $3,82,493$ & 21,671 \\
\hline $1878-79$ & $3,83,878$ & $3,43,789$ & 40,089 \\
\hline $1879-80$ & $3,83,224$ & $3,81,228$ & 1996 \\
\hline $1880-81$ & $7,21,769$ & $5,21,453$ & $2,00,316$ \\
\hline $1881-82$ & $8,05,884$ & $6,03,069$ & $2,02,815$ \\
\hline $1882-83$ & $9,03,914$ & $6,36,558$ & $2,67,356$ \\
\hline
\end{tabular}

Source: The Centenary of Forest Administration in the Madras State,1856-1956, Souvenir, p.x 


\section{Acknowledgement}

My sincere thanks are due to Indian National Science Academy and special word of thanks to the Editor and Associate Editor for their valuable inputs which provided me a great avenue for learning. I also thank the anonymous Referee for his/her insightful comment on the earlier draft of this paper.

\section{Bibliography}

[1] Arnold David and Guha Ramachandra. Nature, Culture, Imperialism Essays on the Environmental History of South Asia, Oxford University Press, New Delhi, 2011.

[2] Balyani Rohit. Indian Forest and Forestry, Pointer Publication, Jaipur, 2012.

[3] Bandopadhyay Arun. The colonial legacy of forest policies in India, Social Scientist, 38.1/2 (Jan-Feb 2010).

[4] Brandis Dietrich. Forestry in India Origin \& Early Developments, Natraj Publishers, Dehra Dun, 1897.

[5] Brandis Dietrich, Indian Forestry, Oriental University Institute, 1897.

[6] Brandis Dietrich. Suggestions regarding Forest Administration in the Madras Presidency, 1883.

[7] Forest Management in Tamil Nadu Past, Present and Future, Tamil Nadu Forest Department, Chennai, 2010.

[8] Imperial Gazetteer of India, Provincial Series, Madras Vol.I, Usha Publications, New Delhi, 1985.

[9] Karunakaran C. K. The Ailing Forests of India, National Book Trust, New Delhi, 2012.

[10] Kumar Deepak. Science and the Raj, Oxford University Press, New Delhi, 2006.

[11] Kumar Ravi V.M. Green colonialism and forest policies in south India, 1800-1900, Environment \& Society Portal, 2010.
[12] Negi S. S. Forestry in Indian Administration, Organisation, Polity \& Legislation Vol. II, MD Publications Private limited, New Delhi, 1997.

[13] Negi S. S. Indian Forestry through the Ages, Indus Publication Company, New Delhi, 1994.

[14] One Hundred years of Indian Forestry, vol I, Souvenir, Government of India Press, New Delhi, 1961.

[15] Rawat S Ajay. History of Forestry in India, Indus Publishing Company, New Delhi, 1991.

[16] Rawat S Ajay, Indian Forestry: A Perspective, Indus Publishing Company, New Delhi, 1993.

[17] Ribbentrop Berthold. Forestry in British India, Indus Publishing Company, New Delhi,1900.

[18] Roy Thirthankar. The Economic History of India 1857-1947, Oxford University Press, New Delhi, 2012.

[19] Stebbing E. P. The Forests of India, vol. I, A. J. Reprints Agency, New Delhi, 1982.

[20] Stebbing E. P. The Forests of India vol. II, John Lane the Bodley Head Limited, London, 1923.

[21] Thurston Edgar. The Madras Presidency with Mysore, Coorg and the Associated States, Asian Educational Services, New Delhi, 2005. 